\title{
Modernistyczne Osiedla Lubelskie będące odpowiedzią na rosnące zapotrzebowania mieszkańców - aspekt synergii
}

\author{
Katarzyna Czapla, Jan Wrana
}

\author{
Samodzielna Pracownia Architektoniczna, Wydział Budownictwa i Architektury, \\ PolitechnikaLubelska,e-mail: katarzyna.czapla@pollub.edu.pl,arch.janwrana@gmail.com
}

Streszczenie: W Lublinie w wyniku zniszczeń wojennych i dużego zwiększenia gęstości zaludnienia, nastąpiła potrzeba wybudowania nowych osiedli mieszkaniowych. Szukano rozwiązania, które w możliwie najkrótszym czasie odpowie na nagłe zapotrzebowanie mieszkaniowe społeczności. Rozwiązaniem problemu okazała się między innymi Lubelska Spółdzielnia Mieszkaniowa (LSM), która składa się z siedmiu modernistycznych osiedli wielkopłytowych o unikalnych układach i podziale funkcji. W artykule podjęto próbę scharakteryzowania wybranych osiedli, porównania ich między sobą jak i podsumowania zalet oraz wad tak ukształtowanych układów urbanistycznych.

Słowa kluczowe: Lublin, osiedla mieszkaniowe, modernizm, wielka płyta, synergia.

\section{Wprowadzenie}

Naturalnym następstwem rozwoju miasta jest jego rozrost. Jak wspomina Leon Krier: „(...) miasta i krajobrazy (...) są rezultatem decyzji politycznych, legislacyjnych i innych, które określają dopuszczalne zagęszczenie obszarów mieszkaniowych, sposób użytkowania terenu, obrys i wysokość zabudowy, jak również kształt, wygląd i znaczenie budynków" [1]. Jednak miasto, jako duży funkcjonujący ,żywy organizm” [2], składa się z mniejszych współdziałających, będących zgraną całością organizmów - dzielnic. Bardzo często dzielnicę można nazwać „Miastem w Mieście” [1], jako częściowo autonomiczny, podstawowy składnik każdego organizmu miejskiego. Dlatego opisując miasto z różnych poziomów należy przeanalizować dzielnice jako oddzielne jednostki, jak i organizmy tworzące w całości miasta.

Lublin jest jednym z przykładów miast, w których z powodu zniszczeń wojennych, stale narastającej liczby mieszkańców oraz bardzo dużej gęstości zaludnienia, doszło do znacznego wzrostu zapotrzebowania na nowe mieszkania. Z racji nagłych potrzeb szukano rozwiązań w postaci nowego, taniego oraz szybkiego budownictwa. Ważnym wyznacznikiem postawionym przez władze miasta była jednakowość lub możliwie najbardziej zbliżone parametry i warunki mieszkań dla wszystkich użytkowników. Sytuacja wymusiła tworzenie nowych osiedli, którym nadano inną niż dotychczas formę i układ urbanistyczny. Nowopowstałe obszary wyróżniały się pod względem funkcjonalności, zagospodarowania, jak i priorytetu obecności człowieka względem wszelkiego rodzaju pojazdów.

Słowo „Synergia”, wywodzące się z języka greckiego, powstałe w wyniku połączenia słów „syn” [razem] i „ergon” [działanie]. Oznacza współdziałanie i interakcje różnych jednostek, które w połączeniu dają większą sumę efektów niż gdyby działały osobno. Ważne dla projektowania nowych układów urbanistycznych, czy architektury jako połączenia formy i funkcji, jest współpraca społeczności użytkującej daną architekturę z przewodnikiem w postaci architekta, czy planisty. W momencie zapotrzebowania na mieszkania, 
priorytetem była ich liczba i jak najkrótszy czas wykonania. Współpraca między jednostkami miejskimi zagwarantowała pomyślność przedsięwzięcia, jednak nie można mówić o współpracy z potencjalnymi mieszkańcami. Dziś obserwujemy powrót do tego co wówczas zawiodło. Mieszkańcy aktywnie uczestniczą w realizacji i uzupełnianiu potrzeb osiedli w celu lepszego i bardziej komfortowego życia. W myśl zasady hasła promującego Lublin „Miasto inspiracji”, miasto ma inspirować, współgrać z jednostkami i tworzyć przyjazne otoczenie rozwoju, realizacji i życia.

\section{Lubelska Spółdzielnia Mieszkaniowa}

W 1957 roku powstała Lubelska Spółdzielnia Mieszkaniowa (LSM). Miasto przeznaczyło około. 360 ha terenu pod obszary planowania osiedli mieszkaniowych. Na tym terenie powstało siedem osiedli: im. Adama Mickiewicza, im. Juliusza Słowackiego, im. Zygmunta Krasińskiego, Piastowskie, im. Henryka Sienkiewicza, im. Bolesława Prusa oraz im. Marii Konopnickiej. Tereny leżące na zachód od głównej osi komunikacyjnej miasta, przekazane pod nowe zabudowy mieszkaniowe były bardzo trudne do zagospodarowania $\mathrm{z}$ racji skomplikowanej rzeźby terenu, wynikiem czego jest potoczna nazwa „Słoneczne Wzgórze". Zamysł zarządu kierującego budową pierwszego osiedla nawiązywał do nazewnictwa osiedli nazwiskami polskich pisarzy, będącymi w założeniu patronami dzielnic, natomiast ulice - od imion literackich bohaterów twórcy. Autorami projektów siedmiu osiedli było pięciu architektów: inż. Feliks Haczewski, inż. Oskara Hansena, inż. Tadeusz Bobek, inż. Antoni Herman, inż. Janusz Link.

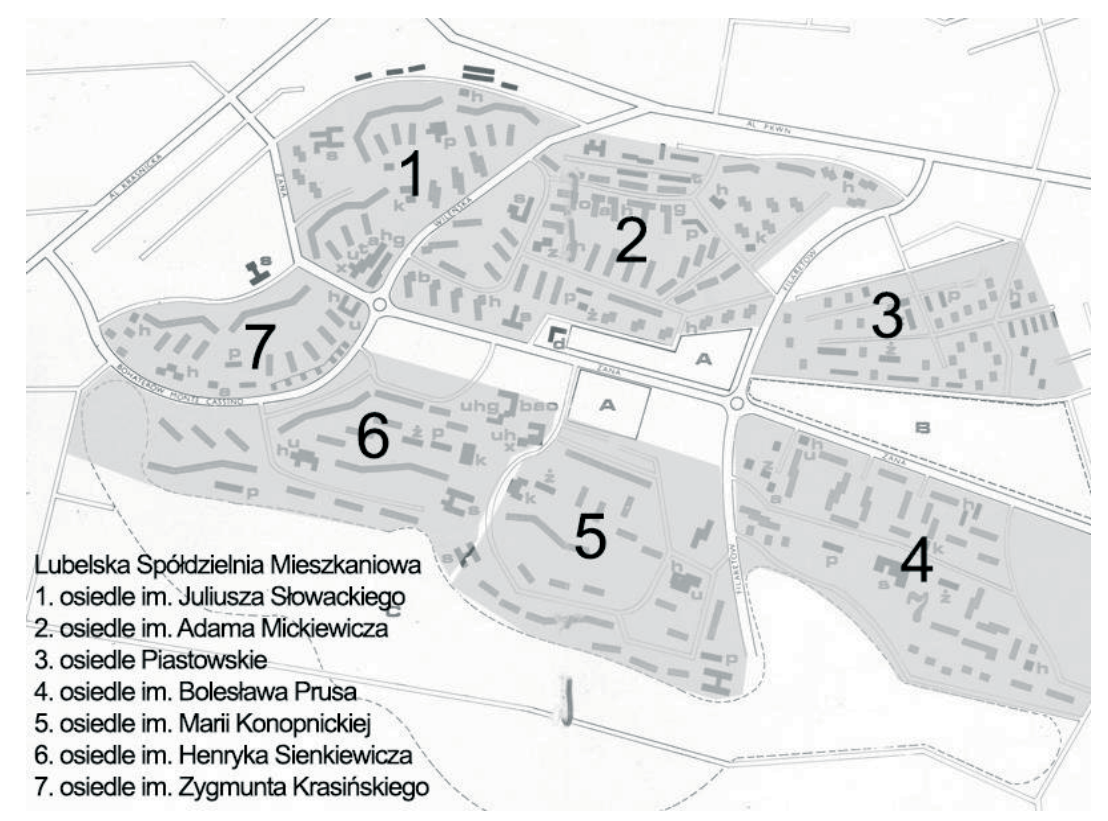

Rys. 1. Osiedla LSM, Opracowanie własne na podstawie [3]

Teren osiedli w momencie wytyczenia pod budowę był zlokalizowany w dużej odległości od ścisłego centrum. Natomiast dzisiaj powstała tu zabudowa z usługami i częściami rekreacyjnymi tworzą „Policentryczne Miasto Społeczności Miejskich” [1]. Za termin ten uważa się miasto posiadające kilka centrów, połączonych ze sobą dopasowaną do potrzeb 
siecią komunikacyjną. Dzięki takiemu założeniu zdaniem Leona Kriera miasto jak organizm tętni życiem dzięki przemieszczaniu się społeczeństwa między licznymi centrami, a miejscem zamieszkania, pracy czy rekreacji. Nie miało to przesłania skrajnie rozumianego jako rozdzielenie wymienionych stref życia ludzkiego między różne części miasta. Strefy te według modernistów powinny być położone możliwe blisko siebie, oszczędzając tym samym czas dojazdów i przemieszczania się między nimi. Krier miał tu na myśli znalezienie równowagi w funkcjonowaniu i korzystaniu $\mathrm{z}$ atrakcji miasta, nie zamykaniu całkowicie się w obrębie jednej dzielnicy.

\section{Osiedle im. Adama Mickiewicza (inż. Feliks Haczewski)}

Po przekazaniu terenu pod budowę przez miasto, osiedle im. A. Mickiewicza było pierwszym jakie wybudowano w dzielnicy LSM. Wyróżniające się na tle innych osiedli stopniem zagospodarowania zieleni, podawane jest jako wzór „Osiedla ogrodu” z racji bardzo korzystnych proporcji powierzchni terenów zielonych do terenów o innym przeznaczeniu. „W latach 70. osiedle zajmowało 42 ha, z czego 20 ha przeznaczone było na tereny zieleni osiedlowej. Tym samym na jednego mieszkańca osiedla przypadało około $38 \mathrm{~m}^{2}$ terenów zieleni "'[4].

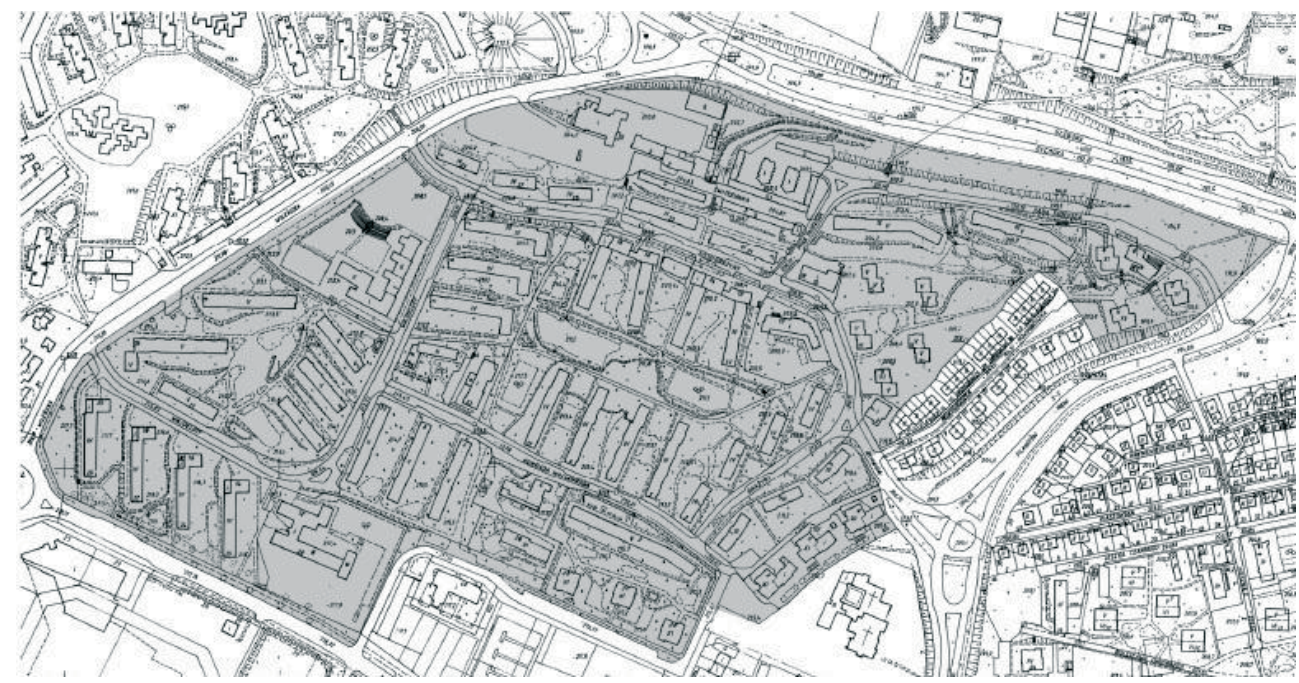

Rys. 2. Osiedle im. Adama Mickiewicza [4]

Główna oś kompozycyjna zarysowuje kształt trapezu wzdłuż ulic: Grażyny, Wajdeloty, Konrada Wallenroda. Przeważa niska zabudowa czteropiętrowych i pięciopiętrowych bloków. Wyróżniający obszar osiedla stanowią dziesięciopiętrowe wieżowce zlokalizowane na obrzeżu zarysu osiedla, będące dominantami oraz wyraźnymi punktami orientacyjnymi. Całość mieszkaniowa dopełniona jest licznymi obiektami użytkowymi takimi jak dwie szkoły podstawowe, żłobek, dwa przedszkola, przychodnia, dom kultury oraz lokale usługowo-handlowe. Przestrzeń pomiędzy budynkami wypełniona jest zielenią dającą wrażenie możliwie najbardziej naturalnej i nie zaplanowanej ściśle i szablonowo. Charakterystycznym punktem jest lokalizacja sadzawki, terenów rekreacyjnych wraz z placami zabaw. Zabudowa została dostosowana do trudnych warunków rzeźby terenu. 


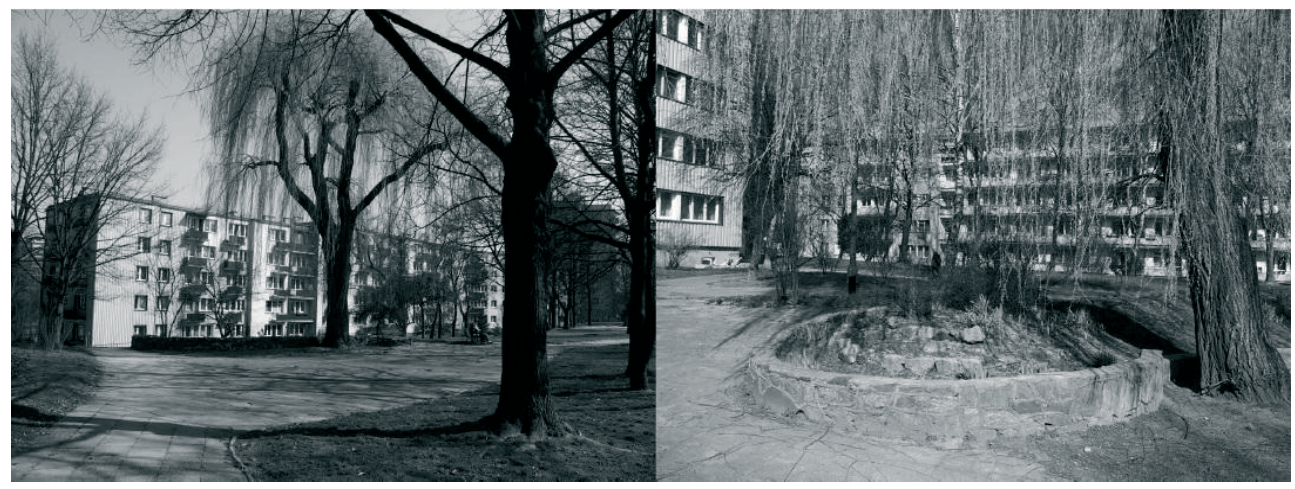

Rys. 3. Osiedle im. Adama Mickiewicza Lubelskiej Spółdzielni Mieszkaniowej (fot. M. Sosnowska) [4]

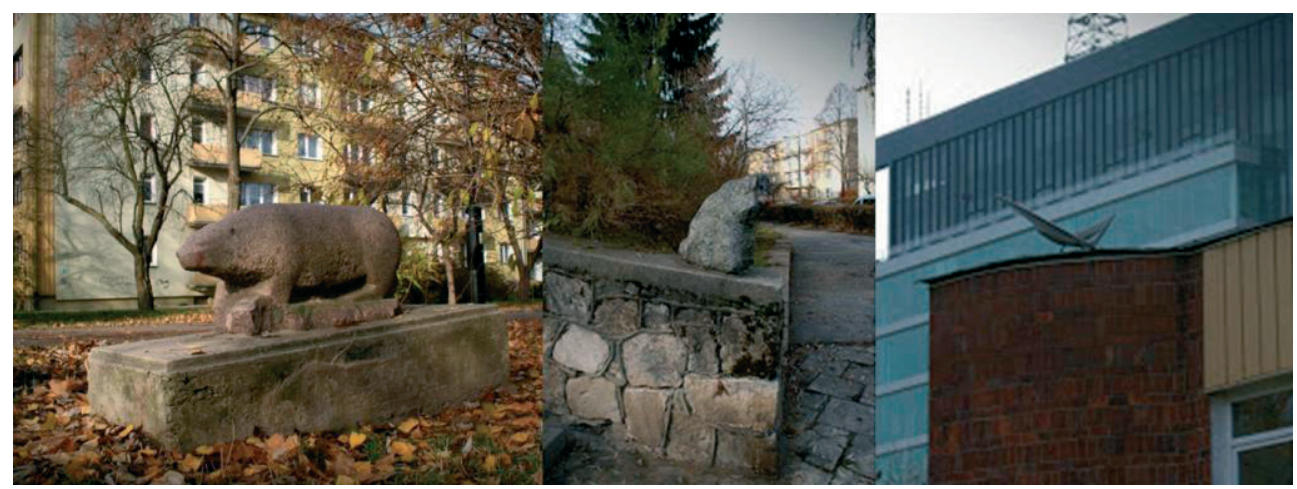

Rys. 4. Rzeźby na osiedlu im. A. Mickiewicza, (fot. Bartłomiej Bałaban)

\section{Osiedle im. J. Słowackiego (Zofia i Oskar Hansenowie)}

Osiedle im. J. Słowackiego jest drugim w kolejności wybudowanym założeniem urbanistycznym o nowatorskim układzie przestrzennym. Koncepcja bazuje na zasadzie „Formy Otwartej”, która zakładała pasmowy podział przestrzeni na strefy o różnych funkcjach. Ważnym założeniem było odejście od tradycyjnego podziału centrum i peryferii. Osiedle zostało podzielone na strefy, z których każda miała pełnić odrębne funkcje. Centralnym elementem założenia jest strefa południowa, będąca tzw. strefą obsługiwaną, w której usytuowano budynki i ogród osiedlowy. Strefa ta pełni funkcje zarówno mieszkalne jak i wypoczynkowe czy zaspokajaniu potrzeb kulturalnych. Jest ona dostępna tylko dla ruchu pieszego. Według nazewnictwa autora, strefa „obsługiwana” została uzupełniona przez dwie strefy „obsługujące”. Stanowią one zaplecze z komunikacją kołową, czyli ruch kołowy, place gospodarcze, parkingi. Osiedle spełnia wymogi zawarte w Karcie Nowej Urbanistyki, uznane jako wzorzec w pewnych kwestiach projektowych: „Funkcje publiczne, administracyjne i komercyjne powinny być zlokalizowane $\mathrm{w}$ dzielnicach i strefach, a nie izolowane w odległych, monofunkcyjnych kompleksach. Szkoły powinny być rozmieszczone tak, aby umożliwić dzieciom dostęp pieszy lub rowerowy”[5]. 


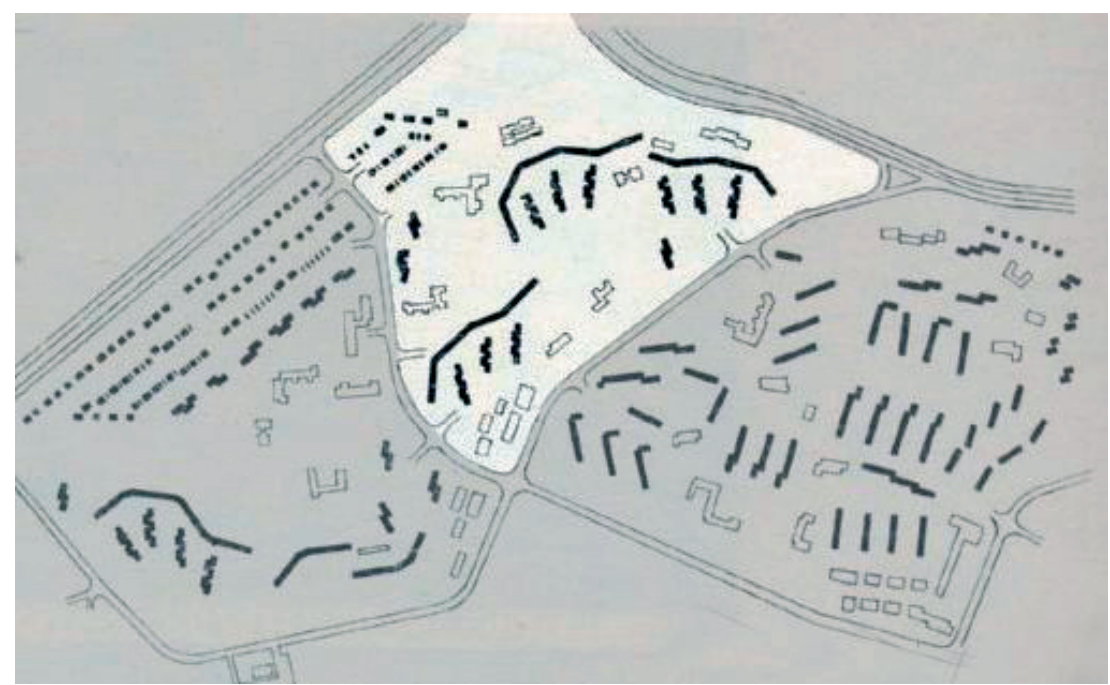

Rys. 5. Osiedle im. J. Słowackiego, LSM. Źródło: Witryna internetowa Teatru NN w Lublinie [6]

Osiedle kształtuje ciąg półkolistych pięciokondygnacyjnych budynków, wraz z zaprojektowaną przez architekta grupą krótkich również pięciokondygnacyjnych bloków mieszkalnych. Koncepcja została są dopełniona przez sześć jedenastokondygnacyjnych wysokościowców. Bloki mieszkalne wykorzystują formę prostopadłościanów z płaskimi dachami. Infrastrukturę osiedla budują dodatkowo: targowisko, budynek przedszkola i budynek usługowo-handlowy. Dachy pawilonów i przedszkola zainspirowane są hiperbolą paraboliczną. Dodatkowym zabiegiem architekta są poprzesuwane względem siebie, nieregularne balkony oraz wejścia główne zlokalizowane od wewnątrz półkolistego placu przenikającego się z osiedlową zielenią. Wnętrza urbanistyczne pozbawione są ruchu kołowego oraz garaży, które zlokalizowane są na obrzeżach osiedla. Jest to celowy zabieg mający postawić na pierwszym miejscu człowieka. Takie zabiegi sprzyjają integracji sąsiedzkiej oraz kontaktom międzyludzkim, co zazwyczaj zanika na osiedlach zbudowanych z bloków mieszkalnych z racji braku poczucia przynależności do społeczności oraz tożsamości miejsca, w którym się żyje.

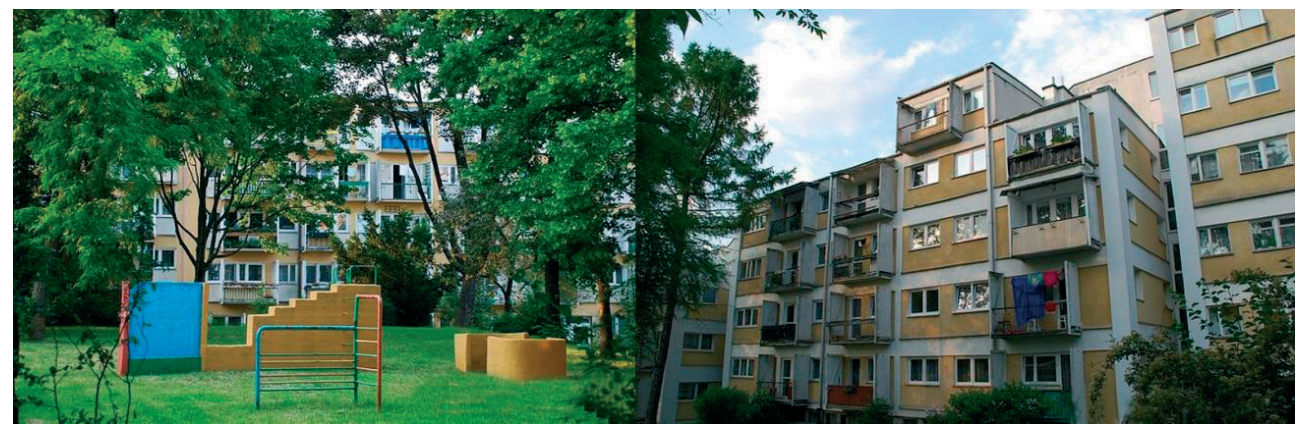

Rys. 6. Osiedle im. J. Słowackiego. Źródło: Witryna internetowa Teatru NN w Lublinie [6]

Oskar Hansen podobnie jak Alejandro Aravena chciał wprowadzić nową metodę współpracy z mieszkańcami. Uważał, że to użytkownicy tych osiedli i budynków powinni być decyzyjni i powinni współpracować z architektem, informując go o swoich wymaga- 
niach, wizjach i pomysłach, a rola architekta powinna ograniczyć się do funkcji doradcy i przewodnika.

Podobnie Alejandro Aravena, przy projekcie Quinta Monroy w Chile pozwalał wprowadzać zmiany do projektów przyszłym mieszkańcom zarówno w formie sugestii w procesie projektowania, jak i budowania i rozbudowywania w późniejszym czasie. Architekt uważał, że takie działanie sprawi, że projekt będzie jeszcze bardziej funkcjonalny i znacznie dopasowany do użytkownika oraz spowoduje to utożsamianie się mieszkańca z miejscem wzbudzając u niego poczucie obowiązku dbania o osiedle/budynek/mieszkanie, ponieważ "Nie można oddzielić egzystencji i przestrzeni egzystencjalnej" [7]. Człowiek potrzebuje pewnego stałego punktu odniesienia. Ma potrzebę przynależności do pewnego "miejsca", poczucia tożsamości oraz „kodu genetycznego miejsca” [8] i integracji z przestrzenią. Jak określał Zbigniew Myczkowski „Tożsamość jest „najgłębszą?” zależnością zachodzącą między percypowanym przez człowieka krajobrazem (otoczeniem) wraz z jego historycznie nawarstwionymi elementami: treścią (kulturą, tradycją miejsca) i formą (kanonem miejsca)."[9]

\section{Osiedle Piastowskie (inż. Antoni Herman)}

Osiedle Piastowskie powstało z okazji 1000-lecia Państwa Polskiego i zostało zlokalizowane między ulicami Filaretów, Głęboką i Zana. Wyróżnia się w założeniu Lubelskiej Spółdzielni Mieszkaniowej samą nazwą, jak i nazwami poszczególnych ulic. Jako jedyne z osiedli LSM-u odbiega tematyką nazewnictwa. Ulice reprezentują imiona królów polskich z dynastii Piastów.

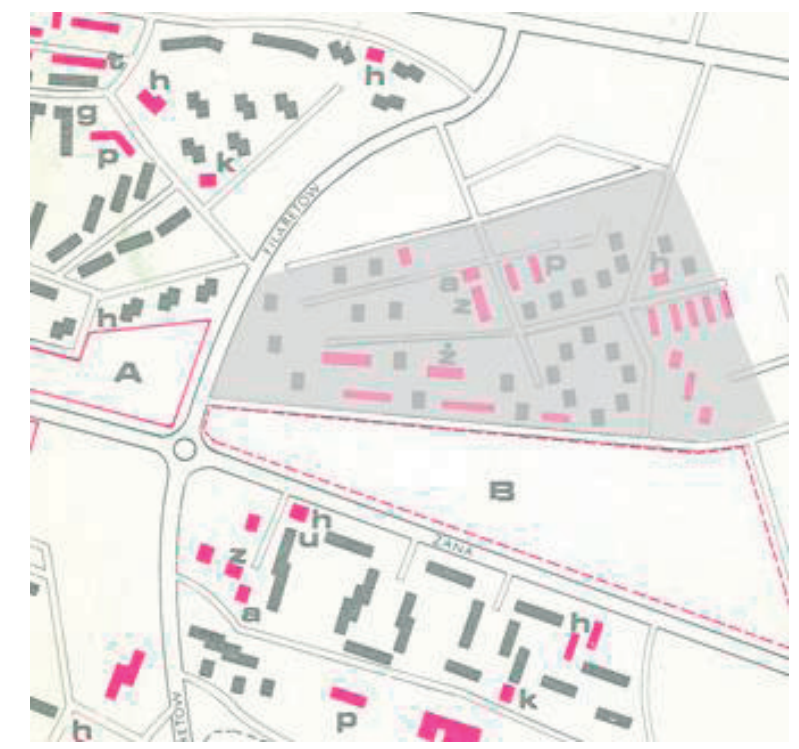

Rys. 7. Osiedle Piastowskie, LSM. Źródło: Mapa: „Nowy Lublin. Osiedla LSM”, LSM 1977, [3], Opracowanie własne

W zabudowie występuje przewaga punktowej zabudowy czterokondygnacyjnej i dziesięciopiętrowych wysokościowców. Wysokościowce stanowią dominanty przestrzenne osiedla i naprowadzają na oś biegnącą na północny zachód, będącą ciągiem komunikacji pieszej, łączącym kolejne osiedla nadziemną kładką pieszą. Odległości między budynkami 
są duże, osiedle wywołuje wrażenie przestrzenności. Liczna wysoka zieleń wypełniająca kwartał od środka, rozrastająca się na obrzeża zarysu daje przyjemne odczucie obcowania $\mathrm{z}$ przyroda $\mathrm{w}$ środku miasta. Wewnątrz osiedla podobnie jak w poprzednich opisanych przykładach komunikacja samochodowa rozprowadzona jest w formie dojazdów na obrzeżach obszaru, wewnątrz przebiegają jedynie ciągi piesze. W centrum znajduje się ogród osiedlowy z sadzawką i fontanną z licznymi tradycyjnymi, standardowymi obiektami małej architektury, ale również z dodatkiem elementów charakterystycznych tylko dla LSM-u w Lublinie. Na osiedlu Piastowskim został umieszony zespół około 50 rzeźb wykonanych z kamienia przez artystów rzeźbiarzy tj. Barbarę Zbrożynę, Jadwigę Janus, Michała Leszczyńskiego. Rzeźby obrazują sceny z historii Polski piastowskiej i są wykonane na podstawie rysunków dzieci.

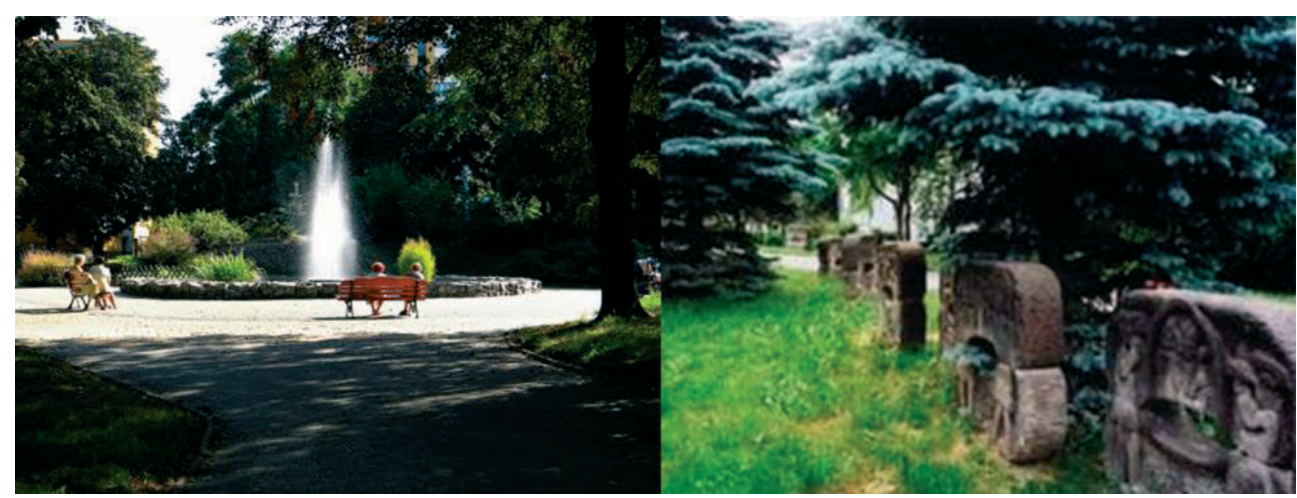

Rys. 8. Fontanna i rzeźby kamienne na osiedlu Piastowskim. Źródło: Witryna internetowa Lubelskiej Spółdzielni Mieszkaniowej [10]

\section{Wnioski}

W Lublinie w odpowiedzi na rosnące zapotrzebowanie na mieszkania powstało wiele funkcjonalnie, jak i urbanistycznie ciekawych założeń urbanistycznych. Wszystkie opisane przykłady mają podobne zasady kreowania i założenia. Pasującym wyznacznikiem kreowania przestrzeni mieszkalnych są zasady zawarte przez Jana Gehla, który napisał, że: „Skala $5 \mathrm{~km} / \mathrm{h}$ to małe przestrzenie, małe znaki, bogactwo detali i bliskość ludzi. Skala $60 \mathrm{~km} / \mathrm{h}$ to wielkie przestrzenie, wielkie znaki i brak detali. Przy tej prędkości nie da się zobaczyć detali ani ludzi” [11]. We wszystkich przestrzeniach najważniejszy jest człowiek i potrzeba równego, jednakowego komfortu mieszkaniowego. Założeniem ogólnym jest wyższy priorytet pieszych nad ruchem kołowym, wyłączenie ruchu kołowego z wnętrza osiedla, zielone wnętrza urbanistyczne, tematyka nazewnictwa, elementy małej architektury stanowiące o tożsamości danego miejsca oraz relacje i układy urbanistyczne między budynkami wykonanymi z wielkiej płyty. Dzielnica LSM, która zaplanowana została przez wybitne jednostki, powstała w bardzo krótkim czasie. Osiedlem powodującym największe dyskusje, skrajną krytykę lub zachwyt, jest osiedle im. J. Słowackiego (Zofii i Oskara Hansena). Niezależnie od tematycznego sporu o trwałości budynków mieszkalnych, technologii oraz staranności ich wykonana, dbanie o osiedla i zachowanie ich z możliwie najmniejszą współczesną ingerencją, leży w gestii społeczeństwa. Układy urbanistyczne powstałe w latach 60 i 70 XX wieku stanowią dobry wzorzec układów i wnętrz urbanistycznych. Mimo problemów zbyt dużych odległości miedzy budynkami, względnie niezagospodarowanej przestrzeni pozostawionej jako zieleń krajobrazowa, całość stanowi o wypełnieniu 
priorytetowego założenia twórców. Osiedla nawiązują do „Osiedla ogrodu”, tworząc przyjemną imitację parkowych wnętrz urbanistycznych. Dzisiejsze próby uzupełnienia braków omawianych terenów, stanowią synergiczne działania społeczności w celu osiągnięcia wspólnego dobra, komfortu, jak i zachowania wartościowych architektonicznie obszarów.

\section{Literatura}

1. Krier L. Architektura Wspólnoty. Wydawnictwo słowo/obraz terytoria, Gdańsk, 2011, s.134, 135.

2. Shokouhi M., Javid M., Fahimeh Yari F., Hossien S. Analysis of field oriented urban planning and architecture with emphasis on application of new technologies in the era of globalization, International, Journal of Applied Science and Technology 2(3) (2012) 263.

3. Gnot L. Nowy Lublin: Osiedla LSM, Lubelska Spółdzielnia Mieszkaniowa, Wojewódzki Ośrodek Informacji Turystycznej w Lublinie Lublin 1977.

4. Sosnowska M. Modernizm powojenny na przykładzie wybranych lubelskich spółdzielczych osiedli mieszkaniowych z lat 60. i 70. XX wieku. "TEKA Komisji Ochrony i Kształtowania Środowiska Przyrodniczego Oddziału PAN w Lublinie, 2008B, s.205-206.

5. Choynowski P., Maciej M. Mycielski (tłumaczenie), Karta Nowej Urbanistyki, Czasopismo Urbanista 6, Warszawa 2005, s.3.

6. Witryna internetowa Teatru NN w Lublinie:

http://teatrnn.pl/leksykon/node/1570/oskar_hansen_osiedle_im_juliusza_s\%C5\%82owackiego_w_lublinie oraz

http://biblioteka.teatrnn.pl/dlibra/dlibra/sresults?action=SearchSimilarAction\&eid=13896 (zdjęcie nr 8 i nr 9)

7. Norberg-Schultz C. Przestrzeń egzystencjalna, [w:] Przestrzeń i architektura, Wydawnictwo MURATOR, Warszawa 2000.

8. Wrana J. Tożsamość miejsca: kryterium w projektowaniu architektonicznym. Politechnika Lubelska, Lublin 2011, s.63-65, 79.

9. Myczkowski Z. Krajobraz wyrazem tożsamości $w$ wybranych obszarach chronionych $w$ Polsce, Monografia 285, PK. Kraków 2003, s. 24

10. Witryna internetowa Lubelskiej Spółdzielni Mieszkaniowej:

http://www.spoldzielnialsm.pl/public/index.php/Strona,Osiedle_Piastowskie,25.html

11. Gehl J. Zmysty i skala [w:] Miasta dla ludzi, Wydawnictwo RAM̄, Kraków 2014, s.44.

\section{Modernist Estate of Lublin as an answer to demands of society - synergy aspect}

\section{Katarzyna Czapla, Jan Wrana}

Independent Laboratory of Architecture, Faculty of Civil Engineering and Architecture, Lublin University of Technologye-mail: katarzyna.czapla@pollub.edu.pl,arch.janwrana@gmail.com

Abstract: War damage caused high density of population and needs to build new housing estate in Lublin. City Government was looking for solution which replied for urgent requests. Lublin Housing Cooperative (LSM) was the solution of the problem. It contains seven most popular prefabricated modernist housing estates with unique urban planning solutions and division functions of estate. The article contains characteristics of selected estates, comparison of each to others and summary of the advantages of these urban planning solutions.

Keywords: Lublin, housing estate, modernist style, prefabricated modernist housing estate, synergy. 